\title{
(Article in Spanish) Un día en la vida: imágenes y símbolos de la guerra civil en El Salvador
}

\author{
William O. Deaver, Jr. ${ }^{1}$
}

This article analyzes the historical accuracy as well as the literary merit of Manlio Argueta's novel, Un dia en la vida. The novel has been listed as one of the 100 most important books of the twentieth century, but is relatively unknown. In fact, the book was banned in El Salvador since it was written during the civil war that ravaged that country in the 1980s. Argueta wrote the novel in exile as a celebration of the resiliency of the Salvadoran population despite the daily struggle to survive in the face of military atrocities that the United States supported through military advisors and financial backing. The novel emphasizes the facelessness nature of domestic terrorism as the military becomes a collective group known as the Authority. A group of related women tells the story of what transpires in a day, but each from a different vantage point. This testimonial structure draws the reader into the novel and serves as a method to present Salvadoran history from the 1930s to the time frame of the novel. [Article copies available for a fee from The Transformative Studies Institute. E-mail address:_journal@transformativestudies.org_Website: http://www.transformativestudies.org (C2013 by The Transformative Studies Institute. All rights reserved.]

KEYWORDS: Argueta, Civil War, El Salvador, Liberation Theology, Oppression, Imperialism, Consciousness, Racism, Propaganda, Torture, Marxism, Testimonial.

\footnotetext{
${ }^{1}$ William O. Deaver, Jr., Ph.D., holds a BA in English and an MA in Spanish from the University of Virginia as well as a Ph.D. in Spanish from Florida State University. He is a professor of Spanish at Armstrong Atlantic State University, where he has taught for the last eighteen years. In addition to teaching, he directs the study abroad program in Mexico and the Latin American Studies Certificate. He has published on Gabriel García Márquez, Mario Vargas Llosa, Pío Baroja, Roberto Fernández, Tomás Gutiérrez Alea, Guillermo del Toro, Miguel Piñero, among others. Address correspondence to: William O. Deaver, Jr ., Languages, Literature, and Philosophy, Armstrong Atlantic State University, 11935 Abercorn Street, Savannah, GA 31419-1997; Tel: (912)344-2799; email: bill.deaver@armstrong.edu.
} 